\title{
Analisis Kemampuan Komunikasi Ilmiah Peserta Didik Pada Kegiatan Kelompok Ilmiah Remaja Berbasis Riset Terintegrasi Keterampilan Proses Sains
}

\author{
Ilah Nurlaelah ${ }^{1}$, Ari Widodo ${ }^{2}$, Sri Redjeki ${ }^{3}$, Taufik Rahman ${ }^{4}$ \\ ${ }^{1}$ Mahasiswa Program S3 SPS Universitas Pendidikan Indonesia \& Program Studi Pendidikan Biologi FKIP \\ Universitas Kuningan, ${ }^{2,3,4}$ Prodi IPA SPS Universitas Pendidikan Indonesia \\ email: ilah.nurlaelah@uniku.ac.id \\ email:widodo@upi.edu \\ email: sriredjeki@upi.edu \\ email: taufikrahman@upi.edu
}
APA Citation: Nurlaelah, I., Widodo, A., Redjeki, S \& Rahman, T. (2020). Analisis Kemampuan Komunikasi Ilmiah Peserta Didik Pada Kegiatan Kelompok Ilmiah Remaja Berbasis Riset Terintegrasi Keterampilan Proses Sains, Quagga: Jurnal Pendidikan dan Biologi, 12(2), 194-2901. doi: 10.25134/quagga.v12i2.2899.

Received: 01-06-2020

Accepted: 29-06-2020

Published:01-07-2020

\begin{abstract}
Abstrak: Penelitian ini bertujuan untuk menggali informasi dan menganalisis profil awal tentang kemampuan komunikasi ilmiah peserta didik. Hasil penelitian ini digunakan untuk merancang program dalam mengembangkan model komunikasi ilmiah dalam Kegiatan KIR terintegrasi pembelajaran berbasis riset. Penelitian ini termasuk ke dalam penelitian eksploratif menggunakan pendekatan kualitatif. Data dikumpulkan menggunakan tes Kemampuan Komunikasi Ilmiah (Tes KKI) dengan indikator kemampuan komunikasi ilmiah meliputi: 1) kemampuan membuat grafik/tabel; 2) kemampuan mendeskripsikan tabel/ gambar/diagram dalam bentuk informasi verbal; 3) kemampuan menginterpretasi; dan 4) kemampuan membuat kesimpulan berdasar data yang tersaji. Data hasil tes kemampuan komunikasi ilmiah dianalisis secara deskriptif yang dikategorikan menjadi tiga kategori yaitu: 1) dapat menjawab dengan lengkap dan disertai penjelasan logis; 2) dapat menjawab tetapi tidak lengkap (tanpa disertai penjelasan logis); 3) tidak menjawab dan tidak ada penjelasan logis. Sejumlah peserta didik anggota KIR Sekolah Menengah Atas di kabupaten Kuningan terlibat dalam penelitian ini dipilih secara purposif. Hasil penelitian menunjukkan kemampuan komunikasi ilmiah masih berada dalam kategori kurang, persentase KKI pada masing-masing indikator masih berada pada angka dibawah $50 \%$.
\end{abstract}

Kata Kunci: kemampuan komunikasi ilmiah, kegiatan KIR berbasis riset, KPS

\begin{abstract}
This study aims to explore information and analyze initial profiles about students' scientific communication skills. The results of this study are used to design programs in developing scientific communication models in KIR activities integrated research-based learning. This research belongs to explorative research using a qualitative approach. The data collected using the Scientific Communication Capability Test (KKI Test) used indicators of scientific communication capabilities as follow: 1) the ability of making graphs / tables; 2) the ability of describing tables / figures / diagrams in the form of verbal information; 3 ) the ability of interpreting; and 4) the ability of making conclusions based on the data presented. The results data from the scientific communication ability test were analyzed descriptively which were categorized into three categories namely: 1) able to answer completely and accompanied by logical explanation; 2) can answer but not complete (without a logical explanation); 3) no answer and no logical explanation. A number of students of KIR High School members in Kuningan district involved in this study were selected purposively. The results showed that the scientific communication skills were still in the inadequate category, the percentage of KKI on each indicator was still below $50 \%$.
\end{abstract}

Keywords: the scientific communication skills, research-based KIR activities, KPS

\section{PENDAHULUAN}

Sains berkaitan dengan cara mencari tahu tentang alam secara sistematis, sehingga sains bukan hanya penguasaan kumpulan pengetahuan yang berupa fakta-fakta, konsepkonsep, atau prinsip-prinsip saja tetapi juga merupakan suatu proses penemuan
(Chiappetta, 2010). Pendidikan sains di sekolah diharapkan dapat menjadi wahana bagi siswa untuk mempelajari diri sendiri dan alam sekitar. Pembelajaran IPA hendaknya memberikan pengalaman belajar pada peserta untuk dapat mengembangkan keterampilan yang dimiliki sekaligus memberikan penguatan 
pada materi yang dipelajari (Chiappetta, 2010). Pendidikan sains menekankan pada pemberian pengalaman langsung untuk mengembangkan kompetensi agar siswa mampu menjelajahi dan memahami alam sekitar secara ilmiah.

Kurikulum sains lebih menekankan agar siswa menjadi pebelajar aktif dan luwes (Undang-undang No. 14, 2005). Pendidikan sains diarahkan untuk "mencari tahu" dan "berbuat" sehingga dapat membantu siswa untuk memperoleh pemahaman yang lebih mendalam tentang alam sekitar (Undangundang No. 14, 2005). Kurikulum sains menyediakan berbagai pengalaman belajar untuk memahami konsep dan proses sains, yang dapat dilakui melalui proses intra, ekstra, dan ko kurikuler. Salah satu program ekstrakuliler yang dapat mendorong penguasaan pengetahuan dan prosses sains adaalh melalui kegiatan Karaya Ilmiah Remaja (KIR). Target pencapaian keikutsertaan siswa dalam KIR perlu sejalan dengan target pembelajaran sains itu sendiri, yaitu kemampuan berkomunikasi ilmiah dan keterampilan proses sains (KPS). Kedua keterampilan tersebut merupkan modal penting bagi siswa dalam menghadpai kehidupan di masyarakat pada abad ke-21 ini.

Kelompok Ilmiah Remaja (KIR) merupakan suatu wadah bagi sekelompok remaja untuk melakukan serangkaian kegiatan yang menghasilkan suatu karya ilmiah. Melalui KIR siswa diharapkan mampu mengembangkan kepekaan terhadap gejala alam yang terjadi di sekelilingnya sekaligus mengembangkan sikap ilmiah siswa (Susilowarno, 2003). Dalam kegiatan KIR berbasis riset siswa dikenalkan bagaimana memahami fenomena alam, mengidentifikasi masalah, merancang kegiatan riset, dan melaporkan hasil. Karya ilmiah yang dihasilkan membantu siswa dalam menerapkan metode ilmiah yang secara tidak langsung mengasah keterampilan proses sains pada siswa, sehingga melalui kegiatan ini dapat memberikan kompetensi pengembangan diri dalam kehidupan (Susilowarno, 2003). Melalui kegiatan kegiatan KIR berbasis riset siswa diajak untuk membuka wawasannya dan melatih kemampuan agar peka terhadap kondisi alam sekitar. Proses investigasi ilmiah yang dialami siswa ketika mengkuti KIR dapat menumbukan KPS (Hidayati, 2011). Beberapa aspek KPS yang dapat dilatihkan melalui kegiatan KIR berbasis riset yang berkaitan dengan kemampuan komunikasi ilmiah diantaranya membaca dan mengkompilasi informasi dalam grafik atau diagram, menggambar data empiris dalam grafik tabel atau diagram, menjelaskan hasil percobaan, menyusun dan menyampaikan laporan secara sistematis dan jelas, menginterpretasi data dan informasi, menghubungkan hasil pengamatan terhadap obyek untuk menarik kesimpulan, dan menemukan pola yang dituliskan dalam tabel suatu fenomena alam.

Komunikasi adalah sebuah proses menghasilkan informasi, mengirim dan signifikasi. Sebagaimana dikutip oleh Hulya Yesil (2010) menyatakan bahwa komunikasi adalah proses psikososial ang menempatkan dua orang ke dalam suatu relasi. Komunikasi adalah proses menghasilkan, mentransfer dan menafsirkan pengetahuan. Dua kemampuan pendukung komunikasi ilmiah adalah berargumentasi ilmiah dan kemampuan merepresentasi data penelitian berupa gambar serta grafik (Hulya Yesil, 2010).

Pentingnya argumentasi dalam pendidikan sains banyak disoroti pada beberapa tahun terakhir (Tuba, D. \& Sedat U, 2002). Argumentasi merupakan bagian yang tidak bisa dipisahkan dari sains. Dalam praktek pembelajaran sains, argumentasi merupakan hal utama yang melandasi siswa dalam belajar bagaimana berpikir, bertindak dan berkomunikasi (Probosari dkk, 2016). Argumentasi ilmiah merupakan salah satu keterampilan berkomunikasi. Menurut Jiménez-Aleixandre dan Erduran (2008) argumen memiliki peranan penting dalam pembelajaran bermakna karena mendukung: a) proses kognitif dan metakognitif, b) pengembangan keterampilan berkomunikasi, (c) eksternalisasi pemikiran siswa sehingga siswa menjadi pemikir yang kritis, c) literasi verbal dan tulisan dalam sains, d) pemahaman tentang budaya dan praktek kegiatan ilmiah, dan e) pengembangan keterampilan penalaran ilmiah. Beberapa hasil penelitian melaporkan bahwa keterampilan argumentasi ilmiah siswa berada pada level 1 sampai 2 dalam kategori rendah hingga sedang (Sudarmo, N.A., A.D Lesmono., dan A. Harijanto, 2018; Devi N.D.C., E. Susanti, dan N.Y. Indriyanti, 2018). 
Dalam komunikasi ilmiah, keterampilan menginterpretasikan grafik dibutuhkan oleh siapapun baik itu peserta didik maupun guru atau calon guru (Didem Kilic et all, 2012). Pemahaman seseorang tentang representasi grafik berkaitan dengan pemahaman akan suatu konsep, dan ini merupakan keterampilan krusial dalam konsep sains. Grafik adalah jenis representasi yang berguna dalam merangkum data, mengolah dan menafsirkan informasi baru dari data yang kompleks. Grafik sering dianggap sebagai perangkat matematika karena berkomunikasi melalui representasi grafik membutuhkan kompetensi matematika seperti persepsi visual, berpikir logis, ploting data, memprediksi gerakan garis, mendeduksi hubungan antara variabel dan lain-lain (Didem Kilic et all, 2012). Dua alasan penting menggunakan grafik, yaitu cara untuk menyimpulkan data dan cara untuk mengkomunikasikan informasi dengan mudah.

Akan tetapi yang terjadi dilapangan, siswa tidak dapat berkomunikasi menggunakan gambar, tabel, grafik atau skema yang sebetulnya hal-hal tersebut meningkatkan kemampuan komunikasi secara lisan. Beberapa penelitian menunjukkan bahwa peserta didik mengalami kesulitan dalam membaca, menafsirkan dan memahami informasi yang disajikan dalam grafik (Didem Kilic, dkk, 2012; Nazan, dkk, 2012; Meltem, dkk, 2012). Begitu pula Nurlaelah (2003) menemukan hampir lebih dari setengah siswa dari sampel yang diteliti masih mengalami kesulitan dalam memahami gambar dan bagan.

Sejalan dengan kemampuan komunikasi ilmiah, pengauasaan KPS oleh siswa juga belum optimal. Padahal penguasaan KPS ini penting dalam membantu siswa mengembangkan pikiran, memberi kesempatan dalam melakukan penemuan, membantu mempelajari konsep-konsep sains, memberi kepuasan instrinsik, dan dapat meningkatkan daya ingat (Dahar, 1998). Hasil penelitian terkait KPS ini sudah banyak dilakukan, beberapa melaporkan bahwa kemampuan KPS siswa bervariasi dalam jenjang dan kriteria KPS yang diukur.

KIR sebagai program ekstrakuliler perlu memfasilitasi kemampuan komunikasi ilmiah dan keterampilan proses sains. Programprogram yang dikembangkan KIR harus dapat melatihkan kedua kemampuan tersebut.
Pembina KIR perlu merancang program yang tepat sehingga KIR dapat mencapai tujuan dengan baik. Dalam rangka mengembangkan program KIR, perlu diketahui gambaran kemampuan awal siswa dalam komunikasi ilmiah dan KPSnya. Perlu dilakukan upaya lebih detil dalam menggali informasi kesulitan peserta didik dalam berkomunikasi ilmiah Gambaran ini menajdi titik awal pengembangan program yang relevan. Oleh karena itu, kajian ini dilakukan dalam rangka memetakan dan menggambarkan kemampuan komunikasi ilmiah dan keterampilan proses sains.

\section{METODE PENELITIAN}

Metode penelitian ini adalah penelitian eksploratif. Metode ini pada umumnya dilakukan dengan tujuan utama, yaitu menggambarkan secara sistematis fakta dan karakteristik objek dan subjek yang diteliti secara tepat (Cresswel, 2007:11; Yin, 2003). Dalam penelitian ini, peneliti beranggapan bahwa metode eksploratif mampu menciptakan pemahaman mendalam terhadap objek atau fenomena yang diteliti, yang dalam hal ini bagaimana profil kemampuan komunikasi ilmiah peserta didik anggota KIR.

Penelitian melibatkan siswa anggota KIR di Sekolah Menengah Atas Kabupaten Kuningan pada kegiatan KIR berbasis riset terintegrasi KPS. Sampel ditentukan secara purposif. Subyek penelitian akan diberikan masalah yang diharapkan dapat menggali informasi tentang tiga jenis keterampilan yang terkait kemampuan komunikasi ilmiah yaitu berkaitan dengan kemampuan membuat grafik, kemampuan mendeskripsikan tabel dan gambar/diagram dalam bentuk informasi verbal, dan kemampuan menginterpretasi serta membuat kesimpulan berdasarkan data yang disajikan.

Data dikumpulkan melalui instrumen soal terkait kemampuan komunikasi ilmiah berupa pemberian tes bentuk uraian tentang kemampuan komunikasi ilmiah. Data hasil tes kemampuan komunikasi ilmiah dianalisis secara deskriptif untuk melihat gambaran keempat kemampuan komunikasi ilmiah sebagai profil dari kemampuan awal tentang komunikasi ilmiah siswa anggota KIR, yang akan dikategorikan menjadi tiga kategori yaitu: 1) dapat menjawab dengan lengkap dan disertai 
penjelasan logis; 2) dapat menjawab tetapi tidak lengkap (tanpa disertai penjelasan logis); 3) tidak menjawab dan tidak ada penjelasan logis.

\section{HASIL DAN PEMBAHASAN}

Temuan hasil penelitian tentang kemampuan komunikasi ilmiah peserta didik anggota KIR disajikan pada tabel 1.

Tabel 1. Persentase Kemampuan Komunikasi Ilmiah

\begin{tabular}{lcccc}
\hline \multicolumn{1}{c}{ Kategori KKI } & $\begin{array}{c}\text { Kemampuan } \\
\text { membuat } \\
\text { tabel/grafik }\end{array}$ & $\begin{array}{c}\text { Kemampuan } \\
\text { mendeskripsikan } \\
\text { tabel/ } \\
\text { gambar/diagram } \\
\text { dalam bentuk } \\
\text { informasi verbal }\end{array}$ & $\begin{array}{c}\text { Kemampuan } \\
\text { menginterpretasi }\end{array}$ & $\begin{array}{c}\text { Kemampuan } \\
\text { membuat } \\
\text { kesimpulan }\end{array}$ \\
\hline $\begin{array}{l}\text { A. Menjawab dengan } \\
\text { lengkap dan disertai } \\
\text { penjelasan logis }\end{array}$ & $41 \%$ & $25 \%$ & $17 \%$ & $69 \%$ \\
\hline $\begin{array}{l}\text { B. Menjawab tetapi tidak } \\
\text { lengkap }\end{array}$ & $51 \%$ & $30 \%$ & $68 \%$ & $28 \%$ \\
\hline $\begin{array}{l}\text { C. Tidak menjawab dan } \\
\text { tidak ada penjelasan logis } \\
\text { Jumlah }\end{array}$ & $8 \%$ & $45 \%$ & $15 \%$ & $3 \%$ \\
\hline
\end{tabular}

Kemampuan komunikasi ilmiah peserta didik yang digali dalam penelitian ini terdiri atas 1) kemampuan membuat tabel/grafik; 2) Kemampuan mendeskripsikan tabel/ gambar/diagram dalam bentuk informasi verbal; 3) Kemampuan menginterpretasi; dan 4) kemampuan membuat kesimpulan, dapat dijelaskan sebagai berikut:

\section{1) Kemampuan peserta didik dalam membuat tabel/grafik}

Secara umum kemampuan membuat tabel/grafik siswa anggota KIR dalam kegiatan KIR berbasis riset menunjukan hasil yang cukup baik. Sebanyak 41\% siswa dapat menjawab soal pada kategori menjawab lengkap disertai penjelasan logis. Fakta ini dapat dipahami bahwa tingkat berpikir siswa semakin tinggi tingkatannya maka secara otomatis juga tingkat berpikir logisnya semakin baik. Kondisi ini didukung hasil penelitian Didem Kilic, Nazan Sezen dan Meltem Sari (2012) yang menemukan fakta terkait kemampuan peserta didik dalam membaca grafik dari tahun pertama sampai tahun keempat walaupun secara statistik ratarata kemampuan membaca grafik masih tergolong rendah. Belma, Yasemin \& Aysun (2010) memperkuat fakta bahwa kemampuan pemodelan peserta didik pada tahap mengobservasi fenomena dan membedakan faktor penting yang mempengaruhi permasalahan sehingga belum mampu mendeskripsikan dengan baik menjadi informasi yang mudah diterima orang lain. Sementara itu sebanyak $51 \%$ peserta didik dapat menjawab namun tidak lengkap, ini artinya $92 \%$ peserta didik secara umum mampu membuat tabel/grafik.

\section{2) Kemampuan peserta didik dalam mendeskripsikan tabel/gambar/diagram dalam bentuk informasi verbal}

Kemampuan siswa anggota KIR dalam mendeskripsikan tabel/gambar/diagram dalam bentuk informasi verbal yaitu $25 \%$ dalam kategori menjawab lengkap disertai penjelasan logis. Fakta ini dapat dijelaskan bahwa ada hubungan self efficacy terhadap kemampuan komunikasi, dimana menurut Mehpare dan Hikmet (2010) bahwa self efficacy berkolerasi positif dengan kemampuan komunikasi peserta didik. Hal ini dapat dijelaskan bahwa keberanian peserta didik dalam mengeksplor data yang dijumpai menjadi kalimat yang baik masih kurang. Siswa hanya memberikan informasi proses tiap-tiap bagian tabel/grafik, dan belum memberikan penjelasan bagian urgensinya, selain itu ketidakberanian dalam mengeksplor data menjadi informasi yang menarik dan dapat dipahami pembaca masih sangat terlihat bahwa mereka kurang bebas dalam memaparkannya. Sementara itu sebanyak $30 \%$ dalam kategori menjawab namun tidak lengkap, ini artinya kemampuan 
mendeskripsikan tabel/gambar/diagram dalam bentuk informasi verbal yaitu $55 \%$.

\section{3) Kemampuan peserta didik dalam menginterpretasi}

Kemampuan menginterpretasi siswa anggota KIR masih sangat kurang, sebanyak $17 \%$ siswa dalam kategori menjawab lengkap disrtai penjelasan logis. Ini terjadi diakibatkan beberapa kesulitan yang dihadapi siswa diantaranya karena kurang teliti dalam menerjemahkan perintah soal, belum mampu mengklasifikasikan data dalam tabel dan mengubahnya dalam bentuk grafik menjadi informasi yang baik sehingga dapat dipahami, serta masih terbatasnya dalam memberikan informasi dan belum menyentuh urgensi dari data yang disajikan. Namun demikian 68\% dalam kategori dapat menjawab namun tidak lengkap, sehingga secara umum sebanyak $85 \%$ siswa memiliki kemampuan menginterpretasi.

\section{4) Kemampuan peserta didik dalam} membuat kesimpulan

Secara umum kemampuan dalam membuat kesimpulan dari data yang tersaji dalam tabel/grafik menunjukkan hasil yang baik yaitu sebanyak $69 \%$ siswa dalam kategori menjawab lengkap disertai penjelasan logis. Fakta ini sangat menarik karena bertolak belakang dengan hasil penelitian Didem Kilic dkk (2012) yang menemukan peserta didik kelas sains di Turki masih lemah dalam membaca grafik, kemampuan merepresentasikan data dan menginterpretasi fenomena banyak dijumpai pada peserta didik kelas sains di Turki. Beberapa kesalahan yang sering dijumpai dalam membaca grafik dan mengekstraksi informasi dari grafik/tabel diantaranya kesulitan dalam penentuan nilai fungsi dan penentuan interval dalam bentuk grafik begitupun penentuan sumbu pada grafik. Kemampuan membuat kesimpulan ini sangat berkorelasi dengan pemahaman terhadap konteks masalah dari wacana yang disajikan dalam soal. Dalam penelitian ini siswa anggota KIR dapat memahami permasalahan sehingga dari bentuk representasi data dalam grafik dapat dengan mudah menentukan kesimpulan yang mana suatu kesimpulan biasanya merupakan jawaban atas permasalahan berdasarkan data yang tersaji dalam grafik/tabel.

Gambar 1 memperlihatkan data persentase kemampuan komunikasi ilmiah peserta didik pada kegiatan KIR berbasis riset terintegrasi keterampilan proses sains pada masing-masing indikator KKI.

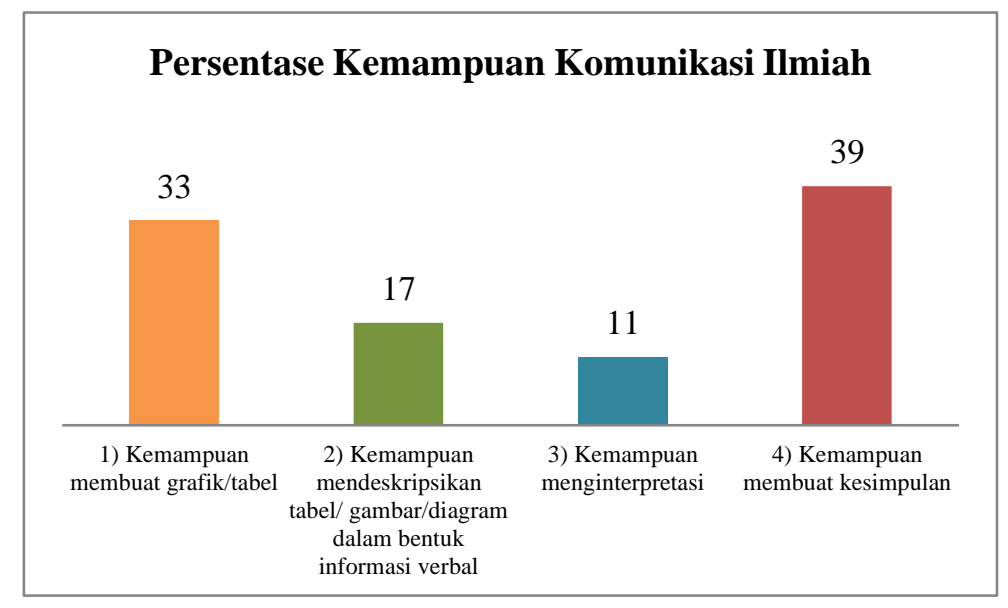

Gambar 1. Persentase KKI Pada Masing-masing Indikator

Fakta-fakta penting dari komponen komunikasi ilmiah dalam dunia pendidikan tercermin dalam beberapa hasil penelitian. Selama ini, performance modelling peserta didik bidang sains masih terbatas pada tahapan mengobservasi fenomena dan membedakan faktor penting yang mempengaruhi masalah, sehingga modeling yang semula masih merupakan bagian dari kegiatan training sangat urgen untuk dimasukkan ke dalam kurikulum menjadi mata kuliah modelling (Belma T, Yasemin S, \& Aysun U, 2010).

Kemampuan membaca grafik peserta didik masih belum maksimal, sehingga perlu dilakukan pembelajaran yang fokus kepada representasi model dan interpretasi fenomena 
sains dan matematika (Didem K, Nazan S, \& Meltem SU., 2012). Di lapangan masih terdapat kendala yang dihadapi peserta didik bidang sains dalam menguasai kemampuan komunikasi ilmiah yaitu termasuk keterampilan grafik, gambar dan bagan. Peserta didik yang sudah mampu membaca grafik ternyata masih belum dapat menyajikan data serupa ke dalam bentuk grafik yang baru (Meltem SU., Nazan S., Ali B., 2012). Dapat disimpulkan dari fakta tersebut bahwa konsep keterampilan proses sains dapat dipahami dengan baik oleh siswa, namun belum terimplementasi pada kinerja mereka.

Telah disadari bahwa perubahan self efficacy peserta didik berkorelasi positif terhadap perubahan keterampilan berkomunikasi. Ini berarti, semakin meningkat keterampilan berkomunikasi, maka semakin meningkat pula sikap profesinya (Hulya Y, 2010). Pada dasarnya peserta didik telah menyadari pentingnya keterampilan komunikasi dalam capaian keberhasilan pendidikan. Disadari pula bahwa sikap mempertahankan keadaan dan kurang berani mengambil langkah dalam melakukan komunikasi akan menghambat proses komunikasi.

Telah ada penelitian yang berupaya meningkatkan kemampuan komunikasi ilmiah dengan mengimplementasikan Argumen Driven Inquiry (ADI) dalam mendukung kemampuan berargumentasi (Tuba D \& Sedat u., 2012). Tahapan-tahapan pendekatan bagi praktisi komunikasi sains juga telah ditemukan (Didem L., Nazan S., \& Meltem SU., 2012). Namun yang paling penting adalah bagaimana menciptakan suasana kondusif dalam proses pembelajaran sehingga tiap komponen keterampilan komunikasi ilmiah dapat dikembangkan secara maksimal. Oleh karena itu, perlu dirancang suatu model komunikasi ilmiah (scientific communication model) peserta didik yang mampu membangun keterampilan komunikasi ilmiah yang baik secara verbal ataupun non-verbal sehingga kendala yang terjadi dapat diatasi dan tujuan pembelajaran keterampilan proses sains terintegrasi kegiatan KIR berbasis riset dapat terwujud.

Sains sebagai produk meliputi sekumpulan pengetahuan yang terdiri atas fakta-fakta, konsep-konsep, teori-teori dan prinsip-prinsip sains, sedangkan sains sebagai proses meliputi keterampilan-keterampilan dan sikap yang dimiliki oleh saintis untuk memperoleh dan mengembangkan produk sains. Keterampilan-keterampilan tersebut merupakan keterampilan proses sains. Dalam pembelajaran IPA/Biologi dengan mengembangkan keterampilan proses, siswa dapat menemukan fakta-fakta, membangun konsep, teori-teori dan sikap ilmiah yang akhirnya dapat berpengaruh positif terhadap proses maupun produk pendidikan.

Menurut Rustaman (2005), keterampilan proses adalah keterampilan yang melibatkan keterampilan-keterampilan kognitif atau intelektual, manual dan sosial. Keterampilan kognitif terlibat karena dengan melakukan keterampilan proses siswa menggunakan pikirannya. Keterampilan manual jelas terlibat dalam keterampilan proses karena mereka melibatkan penggunaan alat dan bahan, pengukuran, penyusunan atau perakitan alat. Keterampilan sosial juga terlibat dalam keterampilan proses karena mereka berinteraksi dengan sesamanya dalam melaksanakan kegiatan belajar-mengajar, misalnya mendiskusikan hasil pengamatan. Keterampilan proses perlu dikembangkan melalui pengalaman-pengalaman langsung sebagai pengalaman belajar. Melalui pengalaman langsung, seseorang dapat labih menghayati proses atau kegiatan yang sedang dilakukan. Menurut Dahar (1998), keterampilan proses sains (KPS) adalah kemampuan siswa untuk menerapkan metode ilmiah dalam memahami, mengembangkan dan menemukan ilmu pengetahuan. KPS sangat penting bagi setiap siswa sebagai bekal untuk menggunakan metode ilmiah dalam mengembangkan sains serta diharapkan memperoleh pengetahuan baru atau mengembangkan pengetahuan yang telah dimiliki (Nworgu \& Otum, 2013). Selain itu, KPS merupakan semua keterampilan yang diperlukan untuk memperoleh, mengembangkan, dan menerapkan konsepkonsep prinsip-prinsip, hukum-hukum dan teori-teori IPA, baik berupa keterampilan intelektual, keterampilan fisik, maupun keterampilan sosial (Rustaman, 2005). KPS terdiri atas keterampilan tingkat dasar dan keterampilan terintegrasi (Nworgu \& Otum, 2013). KPS terintegrasi merupakan 
keterampilan yang menggabungkan beberapa KPS dasar, meliputi keterampilan mengidentifikasi variabel, berhipotesis, mendeskripsikan hubungan variabel-variabel, merencanakan penyelidikan, mengorganisasi data dalam bentuk tabel dan grafik, menganalisis penyelidikan dan data, memformulasikan model, dan memahami hubungan sebab-akibat.

Pembelajaran berbasis riset sangat terkait erat dengan proses inkuiri dan aspek-aspek KPS terintegrasi. Proses inkuiri adalah proses berpikir bila seorang terlibat dalam kegiatan yang meliputi: 1) mengobservasi, 2) meramalkan, 3) menyarankan, 4) merencanakan penelitian, 5) merumuskan hipotesis, 6) menginterpretasikan data, 7) mengontrol variable, 8) melakukan percobaan, 9) mengkomunikasikan. Adanya proses inkuiri dalam pemeblajaran dapat dilihat dari ciri-ciri berikut: 1) cara berpikir dimulai dari pengamatan pada masalah tertentu untuk sampai kepada generalisasi, 2) tujuan pembelajaran adalah memecahkan masalah tertentu yang terdapat pada suatu objek sampai membuat generalisasi tentang objek tersebut, 3) guru sebagai pengontrol data, materi objek dan berperan sebagai pemimpin di dalam kelas, 4) siswa berinteraksi dengan data, materi, objek untuk menemukan pola hubungan berdasarkan pengamatannya dan pengamatan orang lain, 5) kelas dianggap sebagai laboratorium, 6) generalisasi, biasanya tercipta dari siswa, 7) guru mendorong siswa untuk mengkomunikasikan generalisasi yang didapat oleh siswa. Dalam pembelajaran berbasis riset dikembangkan keterampilanketerampilan proses sains. Melalui kegiatan KIR berbasis riset siswa diberi pengalaman yang secara tidak langsung terhadap keterampilan proses sains yang pada hakikatnya merupakan kegiatan inkuiri. Pada akhirnya pengembangan program kegiatan KIR berbasis riset terintegrasi diperlukan demi terwujudnya kemampuan komunikasi ilmiah siswa yang mempuni.

\section{SIMPULAN}

Berdasarkan hasil analisa data, dapat disimpulkan bahwa kemampuan komunikasi ilmiah peserta didik pada kegiatan KIR berbasis riset terintegrasi KPS masih belum cukup baik. Persentase jawaban lengkap dan logis pada masing-masing indikator kemampuan komunikasi ilmiah masih berada pada angka dibawah 50\%. Oleh karena itu, program yang dikembangkan berupa aktivitas pembelajaran yang menekankan pada penguasaan kedua kemampuan tersebut perlu dilakukan. Langkah awal adalah memetakan kompetensi yang belum optomal. Selanjutnya menentukan tujuan program yang relevan dengan peta kompetensi yang perlu dikuasi. Kemudian dilakukan penyusunan program yang relevan beserta perangkat monitoring dan evaluasinya.

\section{REFERENSI}

Belma T, Yasemin S, \& Aysun U. (2010). Preservice reachers performances at mathematical modeling process and views on mathematical modelling. Procedia-social and behavioral sciences 2 (4622-4628).

Chiappetta, E.L., and Thomas R.K.Jr., (2010). Science Instruction in The Middle and Secondary Schools: Developing Fundamental Knpwledge and Skills $7^{\text {th }}$ ed. Pearson Education Inc:Boston.

Cresswell, J.W. (2007). Educational Research: Planning, Conducting, And Evaluating Quantitative And Qualitative Research Fourth Edition. Pearson. United States of America.

Dahar, R.W. 1998. Teori-teori belajar. Erlangga. Jakarta.

Departemen Pendidikan Nasional, 2005. Undang-Undang Nomor 14 Tahun 2005, Tentang Guru dan Dosen, Jakarta: Depdiknas.

Devi N.D.C, E. Susanti dan N.Y Indriyanti, (2018). Analisis Kemampuan Argumentasi Siswa Sma Pada Materi Larutan Penyangga. Jurnal Kimia dan Pendidikan Kimia Vol.3(3) 2018.

Didem K, Nazan \& Meltem S. (2012). A study of pre-service teacher graphing skills. Procedia- social and behavioral sciences 46 (2937-2941).

Hidayati (2011). Pengaruh Kegiatan Ekstrakurikuler Kelompok Ilmiah Remaja (Kir) Terhadap Keterampilan Proses Sains Dan Sikap Ilmiah Siswa Man Brebes 1. FPMIPA UNS. Tidak diterbitkan. 
Hulya Yesil. (2010). The relationship between candidate teachers communication skills and their attitudes towards teaching profession. Procedia- social and behavioral sciences 9 (919-922).

Jiménez -Aleixandre, M. P., \& Erduran, S. (2008). Argumentation in science education: An overview. In S. Erduran \& M. P. Jimenez-Aleixandre (Eds.), Argumentation in science education: Perspectives from classroom-based research (pp. 3-28). Dordrecht, Netherlands:Springer

Meltem S, Nazan S., \& Ali B. (2012). Investigating students abilities related to graphing skills. Procedia-social and behavioral sciences 46 (2942-2946).

Nazan S, Meltem S, \& Ali B. (2012). An investigation of preservice physics teachers use of graphical representations. Procedia-Social and Behavioral Sciences 46 (3006-3010)

Nurlaelah I. (2003). Diagnosis Kesulitan siswa dalam memahami Gambar dan Bagan pada materi Ekosistem. Pendiidkan Biologi FPMIPA Universitas Pendidikan Indonesia. Skripsi. Tidak Dipublikasikan.

Nworgu, L.N. \& Otum, V.V. (2013). Effect of Guided with Analogy Instructional Strategy on Student Acquisition of Science Process Skills. Journal of Education and Practice, 27 (4), p. 35 40.

Probosari R.M, Murni Ramli, Harlita, Meti I, dan Sajidan (2016). Profil Keterampilan Argumentasi Ilmiah Mahasiswa Pendidikan Biologi FKIP UNS pada Mata Kuliah Anatomi Tumbuhan. Bioedukasi Vol 9(1) hal 29-33.

Rustaman, N. 2005. Pengembangan Butir Soal Keterampilan Proses Sains. FPMIPA. UPI.

http://onengdalilah.blogspot.com/2009/0 2

(2005). Strategi Belajar Mengajar Biologi. Malang: Universitas Negeri Malang.

Sudarmo N.A, A.D. Lesmono dan A. Harijanto. (2018). Analisis Kemampuan Berargumentasi Ilmiah Siswa Sma Pada Konsep Termodinamika. Jurnal
Pembelajaran Fisika Vol. 7(2) tahun 2018 hal 196-201.

Susilowarno RG. 2003. "Kelompok Ilmiah Remaja" (Petunjuk Membimbing dan Meneliti Bagi Remaja). Jakarta: Grasindo

Tuba D \& Sedat Ucar. (2012). The effect of argument-driven inquiry (ADI) on preservice science teacher attitudes and argumentation skills. Prrocedia-social and behavioral sciences 46 (5035-5039).

Yin, R.K (2003). Case Study Research Design and Methods Fourth Edition (Applied social research methods v. 5). SAGE Ltd. United States of America. 